\title{
Effect of ethephon application on the cellular maturity of Olea europaea L. and on the extractability of phenolic compounds in virgin olive oil
}

\author{
Youssef Moustakime* , Zakaria Hazzoumi and Khalid Amrani Joutei
}

\begin{abstract}
Background: The effect of the ethephon application at fruit set and veraison on cell maturity of Olea europaea $\mathrm{L}$. olives and on the extractability of phenolic compounds (PC) in virgin olive oil has been studied.

Methods: The ethephon was sprayed on olive trees of the Moroccan Picholine at the fruit set stage and on other olive trees at the veraison stage at a concentration of $100 \mathrm{mg} / \mathrm{L}$. The effect of these treatments was evaluated by the fruit yield and the determination of the period of olives growth and ripening. The extractability of the olive oil and the diffusion of the PCs in the fat as well as the embrittlement of the parietal structures are also monitored.

Results and conclusions: A chemical thinning is entrained out by ethephon when applied at fruit set (16\%) or veraison (12\%). It also results in precocious ripening of fruits treated at fruit set (about 2 weeks) and a precocity of the harvest similar to that induced in olives treated at veraison (estimated at 6 weeks). At this stage, a significant increase in the fat accumulation (more than $26 \mathrm{~g} / 100 \mathrm{~g}$ in the olives treated compared to $7.7 \mathrm{~g} / 100 \mathrm{~g}$ olive pulp in the control) and quantities of extracted oils ( 87 and $83 \%$, respectively, in the olives treated at fruit set and those treated at veraison compared to $70 \%$ in the control) as well as a significant improvement in the extractability of the diffusible PCs in these oils at maturity (540 and $590 \mathrm{mg} / \mathrm{kg}$, respectively, in the treated olives at fruit set and those treated at veraison compared to $216 \mathrm{mg} / \mathrm{kg}$ in the control oil).
\end{abstract}

Keywords: Olea europaea L., Ethephon, Olive oil, Phenolic compounds, Ripening, Chemical thinning

\section{Background}

The ethylene $\left(\mathrm{C}_{2} \mathrm{H}_{4}\right)$ physiology and biochemistry and the use of this phytohormone in agricultural practices have been deeply studied for many decades [1]. The demonstration of the ethylene biosynthetic pathway by Adams and Yang in 1971 and the recent application of molecular biology to unravel the complexities of the biosynthesis and ethylene action have stimulated much research in this field [2-5]. Endogenous or exogenous ethylene leads to numerous responses such as stimulation of pineapple flowering, accelerated maturation of climacteric fruits,

*Correspondence: youssef.moustakime@usmba.ac.ma Laboratory of Bioactive Molecules: Structure and Function, Faculty of Science and Technology Fez, B.P. 2202-Road of Imouzzer, Fez, Morocco abortion of flowers, and development of red spots in lettuce [6].

Moreover, numerous tests have shown the ability of ethylene-releasing chemicals to cause the precocious abscission of the olive trees' fruits [7]. Recent studies on thinning olives using ethephon (ethylene-releasing product) have shown that it can induce precocious pigmentation of drupes when pulverized just after fruit set [8]. Ethylene-releasing chemicals cause the precocious ripening of climacteric fruits, both attached and detached, but only if they are treated during the pre-climacteric period [9]. It also causes precocious ripening of non-climacteric fruits (i.e., cherries and grapes) when applied only a few days before normal ripening [10-13]. 
In addition, several studies show that biosynthesis and the accumulation of phenolic compounds are dependent on hormonal factors: generally, plant growth stimulators (IAA, cytokinins, etc.) have a negative effect on these processes, whereas growth inhibitors (ABA, ethylene, etc.) favor them.

This work aims to study olives ripening and the extractability of phenolic compounds in virgin olive oil by carrying out a treatment with ethephon. The effects of this treatment were assessed by determining changes in physical (weight, diameter, humidity) and biochemical (anthocyanin content, oil accumulation, percentage of oil low, and its content of phenolic compounds) parameters during the ripening of olives. The embrittlement of the parietal structures of fruit estimated by changes in levels of protopectins and the endogenous enzyme activities during the ripening of olives was also determined.

\section{Methods}

\section{Plant material}

This study was carried out on non-irrigated olive trees of the Moroccan Picholine located in the botanical garden of the Faculty of Science and Technology of FezMorocco. These olive trees are of the same age (25 years), the same exposure to the sun, and the same type of soil. For these olive trees, fruit setting stage was estimated at the third week of June 2014.

\section{Treatment of olive trees}

Two treatments with ethephon at $100 \mathrm{mg} / \mathrm{L}$ were carried out by spraying before sunrise during the development and the growth of olives. The trees of this experiment were divided into three lots of 12 trees each: the first was treated with ethephon at fruit set; the second was treated with ethephon at the veraison; and the third and the third untreated as a control. Periodic samples were taken from the veraison to the total maturity of the olives to follow the evolution of the parameters studied.

\section{Moisture determination of olives}

The moisture content of olive drupes was determined gravimetrically according to the UNE standard Spanish method [14].

\section{Determination of total oil content}

The extraction of the total oil content is carried out using hexane in a Soxhlet extractor for $4 \mathrm{~h}$ from the dryer used for the determination of humidity content material [15]. After that, the traces of solvent are removed by evaporation. The determination of the oil content is determined by the weight of dry matter (\% dry weight) and the weight of wet matter (\% wet weight).
Extraction and determination of phenolic compounds (PC) The protocol used for extracting phenolic compounds from olives is that of Brenes et al. [16] with some modifications. Olive pulp $(10 \mathrm{~g})$ was mixed with $30 \mathrm{~mL}$ of a solution of methanol:water $80 / 20(\mathrm{v} / \mathrm{v})$. The mixture was centrifuged for $5 \mathrm{~min}$ at $3500 \mathrm{rpm}$ and then filtered. This extraction was repeated three times. The extracts are collected after evaporation of the organic solvent. Phenolic compounds are extracted with ethyl acetate $(5 \times 20 \mathrm{~mL})$. The extraction of oil polyphenols is performed with methanol according to the method of Vázquez-Roncero and his collaborators [17].

The assay of total polyphenols is based on the reduction of phosphomolybdic acid of Folin-Ciocalteu agent by polyphenols in alkaline medium [18].

The assay of anthocyanins is based on the method used by Ribereau-Gayon and Stonestreet [19] implementing discoloration of flavylium cations by sulfur dioxide.

\section{Isolation and determination of total polysaccharides}

The isolation of pectins is achieved from $50 \mathrm{~g}$ olive pulp according to the procedure of Saulnier and Thibault [20] which implements the precipitation of insoluble material in alcohol (MIA) by several washings with ethanol $95^{\circ}$. From this MIA, successive extractions with water, sodium oxalate, hydrochloric acid, and soda are done.

The assay principle of the pectic substances is based on the colorimetric determination of the galacturonic acid content of the pectic chains hydrolyzed in hot acidic medium of different fractions isolated in the presence of 3-hydroxydiphenyl [21].

\section{Extraction and measurement of endogenous enzyme activities}

One gram of olive pulp was homogenized for $30 \mathrm{~s}$ in $25 \mathrm{~mL}$ potassium phosphate buffer $(0.05 \mathrm{M}, \mathrm{pH}$ 6.6) containing $0.2 \mathrm{~g}$ of Triton X-100 using a Polytron homogenizer. $25 \mathrm{mg}$ polyvinylpyrrolidone (PVPP) was added and the suspension was centrifuged at $4{ }^{\circ} \mathrm{C}$ for $15 \mathrm{~min}$ at $13,000 \mathrm{rpm}$. The supernatant is filtered through glass wool and used as a source of crude enzyme [22]. The various activities are determined as follows:

Polygalacturonase (PG) is assayed by the method of Somogyi [23].

The pectinesterase enzymes (PE) are assayed by the method of Baron [24].

\section{Statistical analyses}

An analysis of variance was performed for each parameter studied. The multiple comparison test averages Tukey post hoc is used to test for significant differences between treatments (at 5\%). Univariate analysis was used 
to test for significant differences in treatment and their interaction for a single parameter. All statistical analyses were performed with IBM SPSS statistics, version 19. The results of every experiment are obtained from triplicates.

\section{Results and discussion}

Determination of the period of growth, maturation, and agronomic indexes during the ripening of the olives treated with ethephon

\section{Influence of ethephon on the period of growth} and maturation of the olives

Table 1 shows the influence of the application of ethephon on Moroccan Picholine olive trees to fruit set and veraison. It is noted that the fruits of the olive trees treated at the time of setting reached veraison 2 weeks earlier and their total maturity in a month and a half compared to those of the controls, respectively. The fruits of olives treated with ethephon at the veraison was matured earlier and reached full maturity also in a month and a half before the olives of the control, as the case of the treatment at fruit set.

\section{Influence of ethephon on the number of fruits per branch}

The exogenous application of ethephon at fruit set or at veraison on olive trees leads to a significant decrease in the number of fruits on the branches (Table 2). This reduction can reach $16 \%$ when the treatment is applied at fruit set and $12 \%$ when the treatment is applied at veraison.

Effect of ethephon on oil extractability and its polyphenol content during the olives ripening

During the olives ripening, the fat content increases in a regular manner from ripening until total maturity (Table 3). This increase follows the increase in weight and diameter and the decrease in olive moisture. Furthermore, fluctuations in the total polyphenols were observed during the ripening of olives, with their contents being increased and decreased at veraison and during the ripening, respectively, and then increased again at maturity.
The treatment of olive trees by ethephon at fruit set (Table 4) allows an accumulation of fat in olive significantly higher than that observed in the control olives and this is from veraison. This increase is concomitant with the increase in the weight and diameter of the olives so that at the total maturity of the fruit these two parameters register values higher than those of the control. The water content of the olives decreases more importantly than the control olives and records lower values from the fruit veraison. On the other hand, the phenolic compounds content in olives are quite high at veraison compared to those of the control. These levels then decrease during maturation before increasing slightly to the total maturity of the fruits, thus reaching a low concentration compared to the control.

The treatment of olive trees with ethephon veraison (Table 5) leads to an acceleration of fruit fat accumulation similar to that observed in olive fruits treated at fruit set (Table 4). At full maturity of the fruit, the accumulation of the fat reaches values significantly higher than those of the control and similar to those of the fruit set treatment. There is also an increase in the weight and diameter of the olives so that, at maturity, they have higher values than in the case of the control and the fruit set treatment. Moreover, the total polyphenol content in fruits increased at veraison and then decreased during maturation achieving a minimum recorded at total maturity. At this stage, the total polyphenol contents are less than those observed in fruits treated at fruit set and in controls.

\section{Effect of ethephon on anthocyanin content}

The accumulation of anthocyanins (Fig. 1) begins at veraison and their grades gradually increase to reach a maximum at total maturity. In fruits treated at fruit set, the appearance of anthocyanins begins 2 weeks earlier than in the controls and their contents increase regularly and rapidly to reach their maxima at total maturity with significantly higher levels than in the controls. When the treatment is applied to veraison, the anthocyanin synthesis is stimulated in an increased and accelerated manner

Table 1 Influence of ethephon on the period of growth and ripening of the olives

\begin{tabular}{|c|c|c|c|c|c|c|c|}
\hline \multirow{2}{*}{ Treatment } & \multicolumn{7}{|c|}{ Period of growth and ripening } \\
\hline & June & July & August & September & October & November & December \\
\hline Control & & & & & & & \\
\hline Ethephon $(\mathrm{N})$ & & & & & & & \\
\hline Ethephon (V) & & & & & & & \\
\hline
\end{tabular}

Ethephon (N): treatment at fruit set; ethephon (V): treatment at veraison; ( I I I I): growth period; ( $\mathbf{L}$ ): ripening period 
Table 2 Influence of ethephon applied at fruit set and at veraison on the yield of olive fruit

\begin{tabular}{|c|c|c|c|}
\hline Treatment & Control & Ethephon (N) & Ethephon (V) \\
\hline $\begin{array}{l}\text { Number of fruits per } \\
\text { branch }\end{array}$ & $94.7 \pm 7.4^{\mathrm{a}}$ & $79.7 \pm 2.5^{b}$ & $82.7 \pm 2.1^{b}$ \\
\hline $\begin{array}{l}\% \text { of gain compared to } \\
\text { control }\end{array}$ & - & $-15.6 \pm 5.2^{b}$ & $-12.2 \pm 8.5^{b}$ \\
\hline
\end{tabular}

so that their contents reach very high values 40 days before those of the control. The rapid and increased synthesis observed in fruit treated at fruit set or veraison leads to a very important precocity in the olives ripening.

\section{Influence of ethephon on the extraction of olive oil during the olives ripening}

The olives accumulate the fat in their cells during maturation. This accumulation begins before veraison and reaches its maximum at the fruit's total maturity (Table 6). The treatment of olive trees at fruit setting results in a very rapid and significant accumulation of the fat in the olives in parallel with the early maturation and this from veraison. These treated olives have accumulated at maturity a $28 \%$ higher fat content compared to the control and $245 \%$ when the same sampling date is considered. Furthermore, the treatment of olives at veraison also stimulates the synthesis of the fat, thus recording values that are significantly higher than those of the control and almost similar to those observed when the treatment is applied to fruit set (28\% higher at maturity and $246 \%$ if the same collection date is considered).

For all treatments, the quantities of extracted oils are very low at veraison, then increase during maturation to reach their maximum values at total maturity (Table 6). The treatment of olive trees at fruit set or veraison results in a rapid and significant increase in the quantities of extracted oils. These extracted quantities are, respectively, 34 and $29 \%$ higher than those of the mature control and 324 and $307 \%$ higher if the same sampling date is taken into account. This rapid increase is the result of the early maturity induced by ethephon estimated at about 6 weeks.

Under these conditions, the extractability of the oil estimated by the percentage of flow is maximum at maturity and may even exceed that of the control. It should be noted that at the maturity of fruits treated at setting and veraison, the flow rates reached almost 87 and $83 \%$, respectively, and only $70 \%$ in the controls.

\section{Effect of ethephon on the total polyphenol contents of extracted oils and their diffusion percentages}

The diffusion of phenolic compounds in the oil from the pulp is very small and represents only a very small amount of the totality of these molecules present in the olives (Table 7). Nevertheless, this rate decreases during maturation and goes from $1.37 \%$ to veraison $0.3 \%$ at maturity.

Table 3 Agronomic indices of control olives during ripening

\begin{tabular}{|c|c|c|c|c|c|c|c|}
\hline \multirow[t]{2}{*}{ Parameter } & \multicolumn{7}{|c|}{ Samples (control) } \\
\hline & S1 (21/09) & S2 (03/10) & S3 (14/10) & S4 (25/10) & S5 (07/11) & S6 (19/11) & S7 (05/12) \\
\hline Weight of 100 olives (g) & $394.1 \pm 7.6$ & $401.4 \pm 5.4$ & $433.8 \pm 7.1$ & $443.4 \pm 3.5$ & $445.5 \pm 2.2$ & $451.12 \pm 2.33$ & $455.9 \pm 3.4$ \\
\hline Diameters (mm) & $17.25 \pm 1.32$ & $17.25 \pm 1.04$ & $17.68 \pm 1.3$ & $17.7 \pm 2.12$ & $17.9 \pm 1.9$ & $17.93 \pm 1.78$ & $18 \pm 2.7$ \\
\hline Moisture content (\%) & $64.4 \pm 0.13$ & $63.6 \pm 0.2$ & $61.9 \pm 0.16$ & $58.7 \pm 0.15$ & $57 \pm 0.11$ & $56.42 \pm 0.46$ & $56 \pm 0.14$ \\
\hline Oil content of olives (g/100 g O.P) & $2.56 \pm 0.35$ & $3.64 \pm 0.19$ & $4.51 \pm 0.33$ & $7.72 \pm 0.39$ & $14.31 \pm 0.43$ & $18.03 \pm 0.43$ & $20.8 \pm 0.51$ \\
\hline T.P content of olives (mg/g O.P) & $58.8 \pm 1.95$ & $69.1 \pm 2.1$ & $50.7 \pm 2.42$ & $52.4 \pm 1.51$ & $54.2 \pm 1.25$ & $66.9 \pm 1.7$ & $69.9 \pm 1.4$ \\
\hline
\end{tabular}

T.P total polyphenols, O.P olive pulp

Table 4 Influence of ethephon at fruit set on agronomic indices of olives during ripening

\begin{tabular}{|c|c|c|c|c|c|}
\hline \multirow[t]{2}{*}{ Parameter } & \multicolumn{5}{|c|}{ Samples ethephon (N) } \\
\hline & S1 (09/09) & S2 (21/09) & S3 (03/10) & S4 (14/10) & S5 $(25 / 10)$ \\
\hline Weight of 100 olives (g) & $386 \pm 9.2$ & $391.5 \pm 7.7$ & $457.2 \pm 5.7$ & $481.8 \pm 4.9$ & $492.8 \pm 3.7$ \\
\hline Diameters (mm) & $17 \pm 1.2$ & $17.1 \pm 1.5$ & $18.4 \pm 0.9$ & $19.1 \pm 1.2$ & $18.8 \pm 1.3$ \\
\hline Moisture content (\%) & $58.9 \pm 0.8$ & $56.4 \pm 0.1$ & $54.3 \pm 0.2$ & $53.2 \pm 0.2$ & $48.5 \pm 0.2$ \\
\hline Oil content of olives (g/100 g O.P) & $4.3 \pm 0.2$ & $4.9 \pm 0.5$ & $8.6 \pm 0.3$ & $16.6 \pm 0.5$ & $26.6 \pm 0.5$ \\
\hline T.P content of olives (mg/g O.P) & $75.2 \pm 1.9$ & $69.6 \pm 1$ & $58.8 \pm 2.3$ & $53.9 \pm 1.5$ & $59.1 \pm 6.5$ \\
\hline
\end{tabular}

Ethephon (N): treatment at fruit set; T.P total polyphenols, O.P olive pulp 
Table 5 Influence of ethephon at veraison on agronomic indices of olives during ripening

\begin{tabular}{lllll}
\hline Parameter & \multicolumn{4}{l}{ Samples ethephon (V) } \\
\cline { 2 - 5 } & S1 (21/09) & S2 (03/10) & S3 (14/10) & S4 (25/10) \\
\hline $\begin{array}{c}\text { Weight of 100 } \\
\text { olives (g) }\end{array}$ & $392.4 \pm 4.9$ & $455.3 \pm 4.7$ & $487.5 \pm 5.4$ & $514.9 \pm 4.4$ \\
$\begin{array}{c}\text { Diameters (mm) } \\
\text { Moisture content } \\
\text { (\%) }\end{array}$ & $17.7 \pm 0.8$ & $19.1 \pm 1.7$ & $19.5 \pm 2.1$ & $19.2 \pm 1.5$ \\
$\begin{array}{c}\text { Oil content of olives } \\
\text { (g/100 g O.P) }\end{array}$ & $2.6 \pm 0.4$ & $7.6 \pm 0.2$ & $16.9 \pm 1.2$ & $26.7 \pm 0.2$ \\
$\begin{array}{c}\text { T.P content of olives } \\
\text { (mg/g O.P) }\end{array}$ & $52.7 \pm 1.8$ & $71.9 \pm 1$ & $56.7 \pm 2.4$ & $52.9 \pm 1$ \\
\hline
\end{tabular}

Ethephon (V): treatment at fruit set; T.P total polyphenols, O.P olive pulp

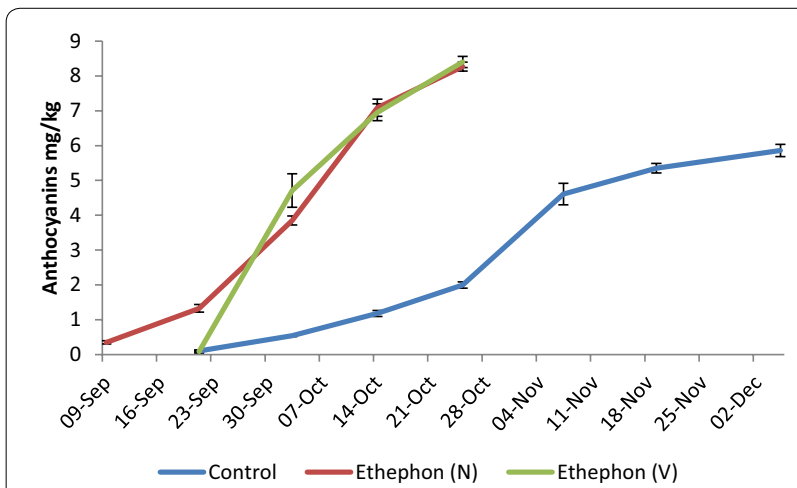

Fig. 1 Influence of ethephon on the anthocyanin contents during the olives ripening: ethephon $(\mathrm{N})$ treatment at fruit set and ethephon (V) treatment at veraison

The olives treated with ethephon at fruit set show a significant increase in total polyphenol contents. On the other hand, this treatment allows to enrich the extracted oils with total polyphenols: at veraison, the oil contents in these compounds increase significantly with a gain of $65 \%$ compared to the control; these contents decrease during ripening so that at the olives that complete maturity, the extracted oils have contents of polyphenols significantly higher compared to the same stage of the control with an estimated gain of $150 \%$.

In the case of the treatment of olives at veraison, the phenolic content increases significantly in olives a few days after the application of the treatment and then begins to decline regularly during maturation until reaching a minimum recorded at full maturity. This treatment also results in a significant increase in the diffusion of the total polyphenols in the oils at veraison, and then this diffusion gradually decreases during maturation, with minimum values at maturity which nevertheless remain very high compared with those of the control. The gain of polyphenol oils at full maturity is about $172 \%$ in comparison with the control at the same stage. This enrichment of the olive oil in total polyphenols is more important than in the case of the fruit setting treatment.

\section{Effect of ethephon applied at fruit set or veraison on cellular embrittlement during the olives ripening Influence of ethephon on the degradation of pectic substances constituting the cell wall during the olives ripening}

At veraison, the constitutive pectins of the cell walls of the olives are mainly constituted by insoluble protopectins. Soluble pectins extracted by water and $\mathrm{Na}$ oxalate represent a small fraction compared to total pectins: the protopectins represent about $90 \%$ of the total pectin (Table 8). During the ripening of the drupe, the protopectin contents decrease regularly and very importantly to represent only about $25 \%$ of their initial contents at maturity. At the same time, there is a regular increase in the soluble pectin content, so that the difference between these two pectin fractions becomes very low at maturity and this is whatever the treatment used.

The application of ethephon, at fruit set or veraison, leads to a very rapid and intense degradation of protopectins (more than $80 \%$ ) from veraison. After 45 days, the difference between the protopectin levels and the soluble pectin content disappears. Under these conditions, protopectins reached low levels precociously compared to the control and even a lower level than that recorded at the total maturity of the control.

\section{Evolution of endogenous enzymatic activities of olives during maturation}

It can be observed from Fig. 2 that the enzymatic activities of PE and PG generally increase during ripening: PE activities increase gradually to a maximum recorded in mid-maturation and then fall to a level lower than that observed at the veraison. PG activities decrease during veraison and then slowly increase during maturation to reach maximum at full maturity. The increase in these activities is accompanied by a decrease in protopectin levels and an increase in soluble pectin levels (Table 8).

The treatment of olive trees by ethephon at fruit setting or at veraison results in a drop in PE activities from veraison. This decrease is observed in the control olives toward the end of ripening. Similarly, PG activities increase rapidly at the beginning of ripening, as in the case of control olives at the end of maturation.

\section{Discussion}

Ethephon (2-chloroethylphosphonic acid) is a systemic plant growth regulator belonging to the phosphonate family. It is readily absorbed by the plant and releases 
Table 6 Influence of ethephon on the total fat in the olives, the quantities of oil extracted, and their flow percentages during the olives ripening

\begin{tabular}{|c|c|c|c|c|c|c|c|c|c|}
\hline \multirow[t]{2}{*}{ Samples } & \multicolumn{3}{|c|}{ Total fat (g/100 g olive pulp) } & \multicolumn{3}{|c|}{$\begin{array}{l}\text { Quantities of oil extracted ( } \mathrm{g} / 100 \mathrm{~g} \text { olive } \\
\text { pulp) }\end{array}$} & \multicolumn{3}{|l|}{$\%$ of low } \\
\hline & Control & $\begin{array}{l}\text { Ethephon } \\
\text { (N) }\end{array}$ & $\begin{array}{l}\text { Ethephon } \\
\text { (V) }\end{array}$ & Control & $\begin{array}{l}\text { Ethephon } \\
\text { (N) }\end{array}$ & $\begin{array}{l}\text { Ethephon } \\
\text { (V) }\end{array}$ & Control & $\begin{array}{l}\text { Ethephon } \\
\text { (N) }\end{array}$ & Ethephon (V) \\
\hline $\begin{array}{l}\text { 09-Septem- } \\
\text { ber }\end{array}$ & - & $4.3 \pm 0.2$ & - & - & $1.3 \pm 0.2$ & - & - & $30.4 \pm 3.2$ & - \\
\hline $\begin{array}{l}\text { 21-Septem- } \\
\text { ber }\end{array}$ & $2.56 \pm 0.35^{\mathrm{a}}$ & $4.9 \pm 0.5^{b}$ & $2.6 \pm 0.4^{\mathrm{a}}$ & $0.65 \pm 0.05^{a}$ & $1.72 \pm 0.2^{b}$ & $0.6 \pm 0.07^{a}$ & $25.8 \pm 4.2^{\mathrm{a}}$ & $35.3 \pm 0.7^{b}$ & $23.2 \pm 1.3^{\mathrm{a}}$ \\
\hline 03-October & $3.64 \pm 0.2^{\mathrm{a}}$ & $8.6 \pm 0.3^{b}$ & $7.6 \pm 0.2^{b}$ & $1.28 \pm 0.03^{\mathrm{a}}$ & $4.72 \pm 0.15^{b}$ & $4.22 \pm 0.14^{b}$ & $35.2 \pm 1.2^{\mathrm{a}}$ & $55.1 \pm 0.6^{b}$ & $55.8 \pm 0.7^{b}$ \\
\hline 14-October & $4.51 \pm 0.33^{\mathrm{a}}$ & $16.6 \pm 0.5^{b}$ & $16.9 \pm 1.2^{b}$ & $2.55 \pm 0.3^{\mathrm{a}}$ & $14.15 \pm 0.1^{b}$ & $13.42 \pm 0.86^{b}$ & $56.5 \pm 3.3^{\mathrm{a}}$ & $85.4 \pm 3.7^{b}$ & $79.4 \pm 3.9^{c}$ \\
\hline 25-October & $7.72 \pm 0.4^{\mathrm{a}}$ & $26.6 \pm 0.5^{b}$ & $26.7 \pm 0.2^{b}$ & $5.43 \pm 0.25^{\mathrm{a}}$ & $23.06 \pm 0.22^{b}$ & $22.1 \pm 0.28^{b}$ & $70.4 \pm 0.5^{\mathrm{a}}$ & $86.8 \pm 0.9^{b}$ & $82.9 \pm 1.8^{c}$ \\
\hline 07-November & $14.31 \pm 0.43$ & - & - & $11 \pm 0.2$ & - & - & $76.9 \pm 1.2$ & - & - \\
\hline 19-November & $18.03 \pm 0.43$ & - & - & $14.2 \pm 0.45$ & - & - & $78.8 \pm 4.2$ & - & - \\
\hline 05-December & $20.8 \pm 0.51$ & - & - & $17.12 \pm 0.4$ & - & - & $82.2 \pm 1.1$ & - & - \\
\hline
\end{tabular}

a, b Values followed by different letters are significantly different $(P=0.05)$

Ethephon $(\mathrm{N})$ : treatment at fruit set, ethephon $(\mathrm{V})$ : treatment at veraison

Table 7 Influence of ethephon on the total polyphenol contents of the extracted oils and their diffusion rates during ripening

\begin{tabular}{|c|c|c|c|c|c|c|c|c|c|}
\hline \multirow[t]{2}{*}{ Sample } & \multicolumn{3}{|c|}{$\begin{array}{l}\text { Total polyphenol content of the olives } \\
\text { (mg/g olive pulp) }\end{array}$} & \multicolumn{3}{|c|}{$\begin{array}{l}\text { Total polyphenol contents diffusible } \\
\text { in extracted oils ( } \mathrm{mg} / \mathrm{kg} \text { pulp of olive) }\end{array}$} & \multicolumn{3}{|c|}{$\%$ of diffusion in oils } \\
\hline & Control & $\begin{array}{l}\text { Ethephon } \\
\text { (N) }\end{array}$ & $\begin{array}{l}\text { Ethephon } \\
\text { (V) }\end{array}$ & Control & Ethephon (N) & Ethephon (V) & Control & $\begin{array}{l}\text { Ethephon } \\
\text { (N) }\end{array}$ & $\begin{array}{l}\text { Ethephon } \\
\text { (V) }\end{array}$ \\
\hline $\begin{array}{l}\text { 09-Septem- } \\
\text { ber }\end{array}$ & - & $75.2 \pm 1.9$ & - & - & $1331.1 \pm 13.9$ & - & - & $1.77 \pm 0.06$ & - \\
\hline $\begin{array}{l}\text { 21-Septem- } \\
\text { ber }\end{array}$ & $58.8 \pm 2^{\mathrm{a}}$ & $69.6 \pm 1^{b}$ & $52.7 \pm 1.8^{\mathrm{a}}$ & $804.6 \pm 47.9^{a}$ & $1291.9 \pm 54.2^{b}$ & $801.3 \pm 10.1^{\mathrm{a}}$ & $1.37 \pm 0.12^{a}$ & $1.86 \pm 0.1^{b}$ & $1.52 \pm 0.04^{\mathrm{a}}$ \\
\hline 03-October & $69.1 \pm 2.1^{\mathrm{a}}$ & $58.8 \pm 2.3^{b}$ & $71.9 \pm 1^{\mathrm{b}}$ & $685.5 \pm 64^{\mathrm{a}}$ & $1017.4 \pm 48.1^{b}$ & $1059.7 \pm 70.8^{b}$ & $1 \pm 0.8^{\mathrm{a}}$ & $1.73 \pm 0.07^{b}$ & $1.47 \pm 0.11^{b}$ \\
\hline 14-October & $50.7 \pm 2.4^{\mathrm{a}}$ & $53.9 \pm 1.5^{b}$ & $56.7 \pm 2.4^{b}$ & $573.7 \pm 54.1^{\mathrm{a}}$ & $692.2 \pm 48^{\mathrm{b}}$ & $715.7 \pm 155^{b}$ & $1.14 \pm 0.16^{\mathrm{a}}$ & $1.28 \pm 0.05^{b}$ & $1.26 \pm 0.21^{b}$ \\
\hline 25-October & $52.4 \pm 1.5^{\mathrm{a}}$ & $59.1 \pm 6.5^{b}$ & $52.9 \pm 1^{\mathrm{a}}$ & $446.5 \pm 91.1^{\mathrm{a}}$ & $539.2 \pm 84.9^{b}$ & $589.3 \pm 147.3^{b}$ & $0.85 \pm 0.15^{\mathrm{a}}$ & $0.92 \pm 0.21^{b}$ & $1.11 \pm 0.26^{b}$ \\
\hline $\begin{array}{l}\text { 07-Novem- } \\
\text { ber }\end{array}$ & $54.2 \pm 1.3$ & - & - & $366.3 \pm 73.3$ & - & - & $0.67 \pm 0.13$ & - & - \\
\hline $\begin{array}{l}\text { 19-Novem- } \\
\text { ber }\end{array}$ & $66.9 \pm 1.7$ & - & - & $306.2 \pm 12.9$ & - & - & $0.46 \pm 0.02$ & - & - \\
\hline $\begin{array}{l}\text { 05-Decem- } \\
\text { ber }\end{array}$ & $69.9 \pm 1.4$ & - & - & $216.1 \pm 74.9$ & - & - & $0.31 \pm 0.11$ & - & - \\
\hline
\end{tabular}

a, b Values followed by different letters are significantly different $(P=0.05)$

Ethephon (N): treatment at fruit set; ethephon $(\mathrm{V})$ : treatment at veraison

ethylene which is a natural plant hormone. Ethylene influences directly several physiological processes and stimulates the production of endogenous ethylene.

The ethephon application on the olive tree of the Moroccan Picholine variety shows important differences in the growth and ripening of olives according to the treatment applied at fruit set or at veraison. Firstly, a significant influence was observed on the fruit yield of these treated olive trees compared to the control olive trees. This parameter is very important since the fruit tree load conditions the quality and the regularity of the fruit at harvest [25]. In fact, when this chemical product releasing ethylene (phytohormone growth inhibitor) was applied at fruit set, it results in a reduction in the fruit crop estimated at $16 \%$ compared to the control and at $12 \%$ when applied at veraison. It is currently known that ethephon, which decomposes in cells to produce ethylene, is one of the substances approved in several countries for its role in the chemical thinning of fruit trees [26]. In the pear Harrow Sweet variety, the use of ethephon in 2008 reduced the fruit load by approximately 29,33 , and $9 \%$ depending on the stage of application of 
Table 8 Influence of ethephon on the contents of various fractions of pectin ( $\mu \mathrm{g}$ galacturonic acids/g dry matter) of olives during ripening

\begin{tabular}{|c|c|c|c|c|c|c|}
\hline \multirow[t]{3}{*}{ Samples } & \multicolumn{6}{|c|}{ Treatment } \\
\hline & \multicolumn{3}{|c|}{ Soluble pectins ( $\mu \mathrm{g}$ galacturonic acids/g dry matter) } & \multicolumn{3}{|c|}{ Protopectins ( $\mu \mathrm{g}$ galacturonic acids/g dry matter) } \\
\hline & Control & Ethephon $(\mathrm{N})$ & Ethephon (V) & Control & Ethephon $(\mathrm{N})$ & Ethephon (V) \\
\hline 09-September & $1846^{a}$ & $1967^{\mathrm{a}}$ & - & $18604^{\mathrm{a}}$ & $14537^{\mathrm{b}}$ & - \\
\hline 21-September & $1928^{\mathrm{a}}$ & $2113^{\mathrm{a}}$ & $1614^{\mathrm{b}}$ & $12888^{\mathrm{a}}$ & $9790^{\mathrm{b}}$ & $16477^{c}$ \\
\hline 03-October & $1771^{\mathrm{a}}$ & $2190^{\mathrm{b}}$ & $2081^{\mathrm{b}}$ & $11613^{\mathrm{a}}$ & $9165^{b}$ & $8996^{\mathrm{b}}$ \\
\hline 14-October & $2525^{a}$ & $2442^{\mathrm{a}}$ & $2452^{\mathrm{a}}$ & $9288^{\mathrm{a}}$ & $6014^{b}$ & $5650^{b}$ \\
\hline 25-October & $2934^{a}$ & $2841^{a}$ & $2792^{a}$ & $7150^{a}$ & $3106^{b}$ & $3628^{b}$ \\
\hline 07-November & 3011 & - & - & 6239 & - & - \\
\hline 19-November & 3198 & - & - & 4572 & - & - \\
\hline 05-December & - & - & - & - & - & - \\
\hline
\end{tabular}

a, bValues followed by different letters are significantly different $(P=0.05)$

Ethephon $(\mathrm{N})$ : treatment at fruit set; ethephon $(\mathrm{V})$ : treatment at veraison

the treatment (i.e., balloon stage, late bloom, and fruit $8-12 \mathrm{~mm}$, respectively) and a reduction of 14,5 , and $17 \%$ for the year 2009 [27]. Studies carried out on the peach «Reedhaven» variety [28] show that ethephon applied 30 days after full flowering (fruits $15-20 \mathrm{~cm}$ in diameter) results in an exponential reduction in yield estimated at $6-11 \%$ for each additional increase of $1 \mathrm{mg} / \mathrm{L}$ (between 0 and $400 \mathrm{mg} / \mathrm{L}$ ). In India, a concentration of $250 \mathrm{mg} / \mathrm{L}$ of ethephon causes the thinning of $75 \%$ of the peach fruit "July Elberta" variety [29].

Very important morphological, physiological, and biochemical modifications accompany these changes in the fruit yield of olive trees under the influence of ethephon. A similar effect of ethephon on the weight, diameter, moisture, and olive fat content is observed when it is applied at fruit set or veraison: a significant increase in fruit weight and diameter with a larger total lipid accumulation. These results disagree with the work of Rugini and his collaborators [30], which showed that concentrations of ethephon (from 0 to $2000 \mathrm{ppm}$ ) do not result in a significant increase in the oil content of olives of the "Giarraffa" variety. Contrariwise, Taheri and his collaborators [28] found that peach weight increases linearly with high concentrations of ethephon, with a 13-15\% increase in fruit size for each additional $1 \mathrm{mg} / \mathrm{L}$ ethephon increase (between 0 and $400 \mathrm{mg} / \mathrm{L}$ ).

On the other hand, ethephon results in precocity of the olive harvest estimated at about 45 days compared to the control, both when the treatment is carried out at fruit set or at veraison. Nevertheless, the fruits from olive trees treated at fruit set reached veraison 2 weeks before the control olives. This advancement in fruit ripening

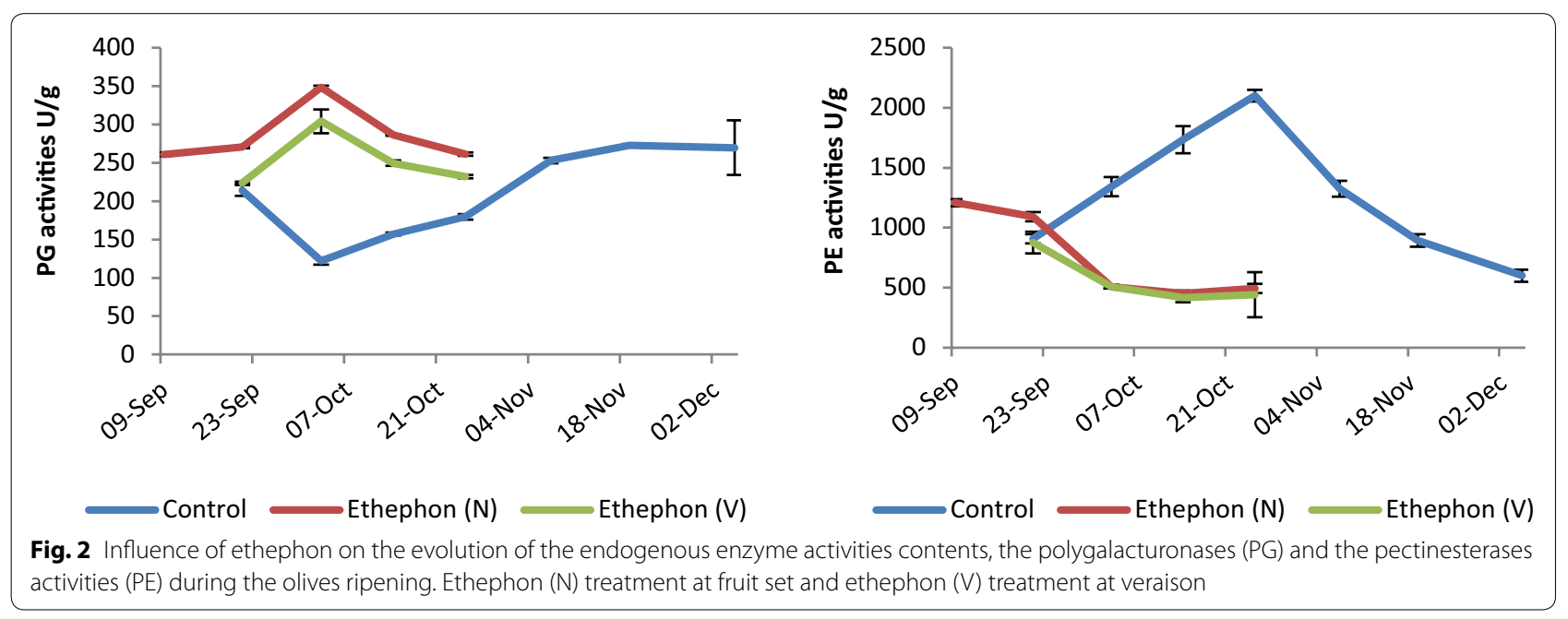


is accompanied by a significant and rapid increase in fruit accumulation of anthocyanin. In fruit from treated olive trees at veraison, ethephon leads to an immediate and intense stimulation of the anthocyanins' synthesis which accompanies the precocious softening of the fruits. These results are in agreement with those of Rujini and his collaborators [30] who showed that ethephon applied 30 days after pit hardening at $2000 \mathrm{ppm}$ causes precocity of the olives " Giarraffa » variety with a significant increase in anthocyanin content. The same authors assume that the effect of ethylene is dependent on the respiratory ratio: ethephon treatments will have a marked effect on olive ripening only when applied prior to the appearance of the maximum respiratory ratio. This is why ethylene-releasing chemical treatments, generally applied to olive trees during the pre-harvest period to facilitate fruit abscission, do not appreciably affect fruit ripening. On the other hand, some work on non-climacteric fruits (cherries, figs, and grapes) showed that ethephon causes precocious ripening when applied only a few days before normal maturation [10-13].

The extraction of olive oil is closely related to the cellular maturity state, itself related to the fragility degree of the parietal and membrane structures of the fruit which constitute a physical barrier preventing the release of the cell contents and the effective recovery of the fat. The fragility of the plant cells is estimated by the protopectin contents which ensure the rigidity of the cell walls. In our case, whatever the treatment, these protopectins decrease during the olives ripening but in a very intense and fast way in the fruit of olive trees treated both at the fruit set and at veraison. This promotes the softening of the parietal and membrane structures of the fruit, thus facilitating the fat flow, and ensures an effective recovery of the virgin olive oil. These results disagree with the work of Mínguez-Mosquera and his collaborators [31] on olives cv. Hojiblanca who observed that protopectin levels remained stable during the olives ripening. Moreover, pectin degradation is closely related to the olives levels in endogenous pectolytic activities. Ethephon influences the activity of these endogenous enzymes regardless of whether the treatment is carried out at fruit set or at veraison. These physiological events result in the more or less intense embrittlement of the parietal structures and the release of cellular contents, leading to a flow of fat estimated at $87 \%$ for the treatment at fruit set and $83 \%$ for the treatment at veraison. The control olives have not yet matured and their percentages of flow have reached only $70 \%$.

Nevertheless, the embrittlement of the cells' parietal structures does not allow an important diffusion of the phenolic compounds in the fat during extraction; a small proportion is found in the oil and this proportion decreases during the olives ripening. The passage of these compounds is related to a modification of the phenolic profile [32]. However, the fruits of olive trees treated by ethylene show an increase in the cellular fragility from the veraison compared to the control following a rapid and intense degradation of the parietal structures. These observations are confirmed by the very important decrease in pectins and the increase in pectolytic activities, mainly the PG activities, which allow the degradation of protopectins. This phenomenon is observed as soon as the olives are treated, both at fruit set and at veraison. These results are in agreement with those of Amrani on grapes [10] and of Agravante and his collaborators [33] and Lohani and his collaborators [34] on the banana ripening. Furthermore, the study of gene expression encoding the parietal hydrolases showed that most of them are induced during ripening and regulated by ethylene [35-38]. These physiological processes allow embrittlement of the olives' cell walls, which has the consequence of facilitating the release of the phenolic compounds and the enrichment of the virgin olive oil by these compounds. Thus, the treatment of olive trees by ethylene at fruit set or veraison makes it possible to extract at total maturity an oil rich in total polyphenols with a gain of these compounds at about 150\% in comparison with the phenolic charge of oils of the control olives.

\section{Conclusion}

The application effect of ethephon on cell maturity, fat extractability, and diffusion of phenolic compounds in virgin olive oil during the olives ripening of the Moroccan Picholine variety has been studied. In this study, we have shown that the treatment of olive trees by ethephon at fruit set or veraison produces chemical thinning of the fruit and very important precociousness of the harvest due to an increase in the endogenous pectolytic activities which result in a very rapid and intense decrease in the protopectin contents, thus facilitating the fat flow and a very important diffusion of the PCs in the virgin olive oil.

\section{Abbreviations}

ABA: abscisic acid; IAA: indole-3-acetic acid; MIA: insoluble material in alcohol; PC: phenolic compound; PE: pectinesterase enzymes; PG: polygalacturonase.

\section{Authors' contributions}

The author YM assured the application of the treatments and the samples during the period of ripening of olives and the analyses in the laboratory. In addition, he contributed to the writing of the manuscript. The author ZH assured the processing of the samples (extraction of olive oil, preparations of phenolic and enzymatic extracts) and contributed to the writing of the manuscript.

The author KAJ assured statistical treatment of the results obtained and also contributed to the writing of the manuscript. All authors read and approved the final manuscript. 


\section{Acknowledgements}

Not applicable.

\section{Competing interests}

The authors declare that they have no competing interests.

\section{Availability of data and materials}

Not applicable.

\section{Consent for publication}

Not applicable.

\section{Ethics approval and consent to participate}

Not applicable.

\section{Funding}

Nil.

\section{Publisher's Note}

Springer Nature remains neutral with regard to jurisdictional claims in published maps and institutional affiliations.

Received: 10 July 2017 Accepted: 14 December 2017

Published online: 18 January 2018

\section{References}

1. Abeles FB, Morgan PW, Saltveit ME. Ethylene in plant biology, vol. 15. 2nd ed. San Diego: Academic Press; 1992.

2. Yang SF. Biosynthesis and action of ethylene. HortScience. 1985;20:41-5.

3. DellaPenna D, Giovannoni JJ. Regulation of gene expression in ripening tomatoes. In: Grierson D, editor. Developmental regulation of plant gene expression. Glasgow: Blackie; 1991. p. 182-216.

4. Grierson D, Schuch W. Control of ripening. In: Bevan MW, Harrison BD, Leaver CJ, editors. The production and uses of genetically transformed plants. London: Chapman and Hall; 1994. p. 53-62.

5. Kanellis AK, Chang C, Kende H, Grierson D. Biology and biotechnology of the plant hormone ethylene. Boston: Kluwer Academic Publishers; 1997.

6. Saltveit ME. Relationship between ethylene production and taste panel preference of Starkrimson red delicious apples. Can J Plant Sci. 1983:63:303-6.

7. Blumenfeld A, Epstein E, Bental Y. Ethylene treatment and abscission of olive fruits. HortScience. 1978;13:47-8.

8. Fontanazza G, Rugini E. Ensayos preliminares sobre el uso de fitoreguladores en el aclareo del olivo. Olea: Diciembre; 1979. p. 18-29.

9. Yamaguchi M, Chu CW, Yang SF. The fate of ${ }^{14} \mathrm{C}$ (2-chloroethyl) phosphonic acid in summer squash, cucumber, and tomato. J Am Soc Hort Sci. 1971;96:606-9.

10. Amrani Joutei K. Contribution à l'étude des composés phénoliques des raisins: influence des phytohormones et rôle des activités protéolytiques et pectolytiques purifiées. Thèse de Doctorat d'Etat. Faculté des Sciences et Techniques, Université Sidi Mohamed Ben Abdellah. Fès-Maroc; 2005.

11. Bukovac M, Zucconi JF, Wittenbach VA, Flore JA, Inque H. Effects of (2-chloroethyl)phosphonic acid on development and abscission of maturing sweet cherry (Prunus avium L.) fruit. J Am Soc Hort Sci. 1971;96:777-81.

12. Puech AA, Rebeiz CA, Crane JC. The effects of 2-chloroethyl phosphonic acid on pigment changes in the Mission fig fruit. Plant Physiol. 1971;47:89 (Abstr.).

13. Weaver RJ, Pool RM. Effect of (2-chloroethyl)-phosphonic acid (ethephon) on maturation of Vitis vinifera L. J Am Soc Hort Sci. 1971;96:725-7.

14. Aenor, Associación Española de Normalización y Certificación. Materias Grasas. Humedad y materias volatiles (Mètodo de la estufa de aire) (Norma UNE 55-020-73, Madrid, España); 1973.
15. Aenor, Associación Española de Normalización y Certificación. Cuerpos Grasos. Determinación del contenido en material grasa total de la aceituna. (Norma UNE 55030, Madrid, España); 1961.

16. Brenes M, Rejano L, Garcia P, Sanchez HA, Garrido A. Biochemical changes in phenolic compounds during Spanish-style green olive processing. J Agric Food Chem. 1995;43:2702-6.

17. Vázquez-Roncero A, Janer del Valle C, Janer del Valle ML. Determinación de polifenoles totales del aceite de oliva. Grasas Aceites. 1973;22:350-5.

18. Catalano L, Franco I, De Nobili M, Leita L. Polyphenols in olive mill waste waters and their depuration plant effluents: a comparison of the FolinCiocalteu and HPLC methods. Agrochimica. 1999:43:193-205.

19. Ribereau-Gayon P, Stonestreet E. Le dosage des anthocyanes dans le vin rouge. Bull Soc Chim. 1965;9:2649-52.

20. Saulnier L, Thibault JF. Extraction and characterization of pectic substances from pulp of grape berries. Carbohyd Polym. 1987;7:329-43.

21. Robertson GL. The fractional extraction and quantitative determination of pectic substances in grapes and musts. Am J Enol Vitic. 1979;30(3):182-6.

22. Jesús Tovar M, Paz Romero M, Girona J, Motilva MJ. L-Phenylalanine ammonia-lyase activity and concentration of phenolics in developing olive (Olea europaea L. cv Arbequina) fruit grown under different irrigation regimes. J Sci Food Agric. 2002;82:892-8.

23. Somogyi M. Notes on sugar determination. J Biol Chem. 1952;195:19.

24. Baron A. Norme française homologuée de détermination des substances pectiques T2. I/MGS/CSM, 0314 et 0607700; 1984.

25. Baab G, Lafer G. Kernobst: Harmonisches Wachstum-optimaler Ertrag. Leopoldsdorf: Österreichischer Agrarverlag; 2005. p. 163.

26. Widmer A, Chriten D. Guide phytosanitaire pour l'arboriculture fruitière 2010/2011. Régulation de la charge par éclaircissage chimique. Revue Suisse Vitic Arboric Hortic. 2010;42(1):56-7.

27. Christen D, Chassot E, Widmer A, Gölles M. Eclaircissage chimique sur poiriers : efficacité et influence sur la production et la qualité de différentes variétés. Revue suisse Vitic Arboric Hortic. 2010;42(3):170-8.

28. Taheri A, Cline JA, Jayasankar S, Pauls PK. Ethephon-induced abscission of 'Redhaven' peach. Am J Plant Sci. 2012;3:295-301. https://doi. org/10.4236/ajps.2012.32035.

29. Sharma MR, Gautam DR. Note on ethephon for thinning peach fruit. Indian J Agric Sci. 1981;51:362-4.

30. Rugini E, Bongi G, Fontanazza G. Effects of ethephon on olive ripening. J Am Soc Hort Sci. 1982;107(5):835-8.

31. Mínguez-Mosquera I, Gallardo-Guerrero L, Roca M. Pectinesterase and polygalacturonase in changes of pectic matter in olives (cv. Hojiblanca) intended for milling. JAOCS. 2002;79(1):93-9.

32. Moustakime Y, Hazzoumi Z, Amrani Joutei K. Effect of proteolytic activities in combination with the pectolytic activities on extractability of the fat and phenolic compounds from olives. SpringerPlus. 2016;5:739.

33. Agravante JU, Matsui T, Kitagawa H. Changes in pectin methylesterase, polygalacturonase and pectic substances of ethanol- and ethylenetreated bananas during ripening. Nippon Shokuhin Kogyo Gakkaishi. 1991;38(6):527-32.

34. Lohani S, Trivedi PK, Nath P. Changes in activities of cell wall hydrolases during ethylene-induced ripening in banana: effect of 1-MCP, ABA and IAA. Postharvest Biol Technol. 2004;31:119-26.

35. Fisher RL, Binnett $A B$. Role of cell wall hydrolases in fruit ripening. Annu Rev Plant Physiol Plant Mol Biol. 1991;42:675-703.

36. Harriman RW, Tieman DM, Handa AK. Molecular cloning of tomato pectin methylesterase gene and its expression in Rutgers, ripening inhibitor, nonripening, and never ripe tomato fruits. Plant Physiol. 1991;97:80-7.

37. Gonzalez-Bosch C, Brummell DA, Bennett AB. Differential expression of two endo-1,4-beta-glucanase genes in pericarp and locules of wild-type and mutant tomato fruit. Plant Physiol. 1996;111:1313-9.

38. Smith DL, Starrett DA, Gross KC. A gene coding for tomato fruit betagalactosidase II is expressed during fruit ripening. Cloning, characterization, and expression pattern. Plant Physiol. 1998;117:417-23. 